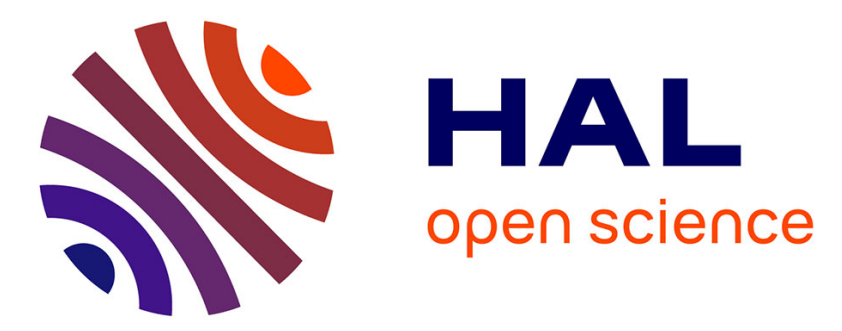

\title{
A flexible radical approach to 5 -substituted 4,5-dihydro-3H-pyrido[4,3-b]azepin-2-ones. Some mechanistic observations on the radical cyclisation-aromatisation process
}

Laurent Petit, I. Botez, A. Tizot, Samir Z. Zard

\section{To cite this version:}

Laurent Petit, I. Botez, A. Tizot, Samir Z. Zard. A flexible radical approach to 5substituted 4,5-dihydro-3H-pyrido[4,3-b]azepin-2-ones. Some mechanistic observations on the radical cyclisation-aromatisation process. Tetrahedron Letters, 2012, 53 (26), pp.3220-3224. 10.1016/j.tetlet.2012.04.020 . hal-00949980

\section{HAL Id: hal-00949980}

https://hal-polytechnique.archives-ouvertes.fr/hal-00949980

Submitted on 14 Apr 2014

HAL is a multi-disciplinary open access archive for the deposit and dissemination of scientific research documents, whether they are published or not. The documents may come from teaching and research institutions in France or abroad, or from public or private research centers.
L'archive ouverte pluridisciplinaire HAL, est destinée au dépôt et à la diffusion de documents scientifiques de niveau recherche, publiés ou non, émanant des établissements d'enseignement et de recherche français ou étrangers, des laboratoires publics ou privés. 


\title{
A flexible radical approach to 5-substituted 4,5-dihydro-3H-pyrido[4,3-b]azepin- 2-ones. Some mechanistic observations on the radical cyclisation-aromatisation
} process

\author{
Laurent Petit ${ }^{\mathrm{a}}$, Iuliana Botez ${ }^{\mathrm{b}}$, André Tizot $^{\mathrm{b}}$, Samir Z. Zard ${ }^{\mathrm{a}, \Uparrow}$ \\ ${ }^{a}$ Laboratoire de Synthèse Organique, UMR 7652 CNRS, Ecole Polytechnique, 91128 Palaiseau, France \\ ${ }^{\mathrm{b}}$ Institut de Recherches Servier (IdRS), 125 chemin de Ronde, 78290 Croissy sur Seine, France
}

a b s t r a c t

Variously substituted novel dihydropyridoazepinones have been prepared by an intermolecular radical addition followed by a radical cyclisation on a pyridine ring. The latter process involved the use of a com- bination of two different peroxides, an experimental contrivance resulting from a careful product analysis and a better understanding of the cyclisation step.

Pyridine derivatives arguably represent a very important class of heterocyclic structures. They are used in a wide variety of applications such as pharmaceuticals, agrochemicals, vitamins, food flavourings, paints, dyes, rubber products, adhesives, etc. Thus, their preparation has garnered much interest in both academic and industrial settings. ${ }^{1}$ The search for innovative and efficient access to this class of molecules is indeed one of the driving forces in this field. The degenerative transfer of xanthates and related groups discovered in our laboratory has proved efficient at accomplishing notoriously difficult radical transformations such as intermolecular additions to unactivated alkenes and ring-closure onto aromatic rings. ${ }^{2}$ In this context, we have explored the synthesis of heterocyclic substructures using either a radical cyclisation onto the relevant aromatic ring or a combination of an intermolecular addition and a radical cyclisation. For example, azaindolines, diazaindolines, pyrimidinones, azaindoles, azaoxindoles, pyridones, tetrahydronaphthyridines and tetrahydroazaquinolones have all been assembled using this technology in a straightforward fashion. ${ }^{3}$ Seven-membered rings fused to a pyridine core, such as pyridoazepines, are very scarce structures in the chemical literature, reflecting the difficulty of their access. Yet, they can be valuable targets, as demonstrated by the considerable effort invested by the process research department at Merck to develop a practical route to a non-peptidic avb3 antagonist containing a tetra-

\footnotetext{
介 Corresponding author.

E-mail address: zard@poly.polytechnique.fr (S.Z. Zard).
}

hydropyridoazepine ring (Scheme 1 ). ${ }^{4}$ To date, the most useful method to construct this scaffold relies on the ortho-metalation of an $\mathrm{N}$-acyl-aminopyridine followed by alkylation with a dihaloalkane and in situ cyclisation. However, this method, introduced by Spivey in 1998 for the synthesis of DMAP analogues, ${ }^{5}$ is hampered by the limited access to suitable dihaloalkanes and by the low functional group tolerance inherent to the use of strong lithiated bases. We have reported a radical based approach to two examples of 6,7-dihydro-5H-pyrido[2,3-b]azepin-8(9H)-one (the extra-nuclear nitrogen atom is at the 2-position of the pyridine), but further investigation was required to generalise this strategy and to extend it to the synthesis of other isomers in this family. ${ }^{2 b}$

We became interested in molecules bearing the nitrogen substituent at the 4-position of the pyridine ring because these isomers are virtually unknown in the literature. ${ }^{6}$ Our synthetic analysis relies on a sequence consisting of an intermolecular radical addition of a xanthate to an unactivated olefin such as 1 to furnish xanthate 2 , followed by the radical cyclisation to give 3 (Scheme 2). The chlorines at the 2- and 6-positions were chosen to reduce the nucleophilicity and basicity of the pyridine nitrogen atom and to serve as further points of diversification. ${ }^{2 b}$ A nucleophilic pyridine slowly decomposes the xanthate group by an ionic process and the resulting sulphur-containing products can interfere with the radical sequence.

Initial studies revealed that the nitrogen atom at the 4-position needed to be substituted for the cyclisation to occur; otherwise, almost complete reduction of the xanthate function in 2 was 


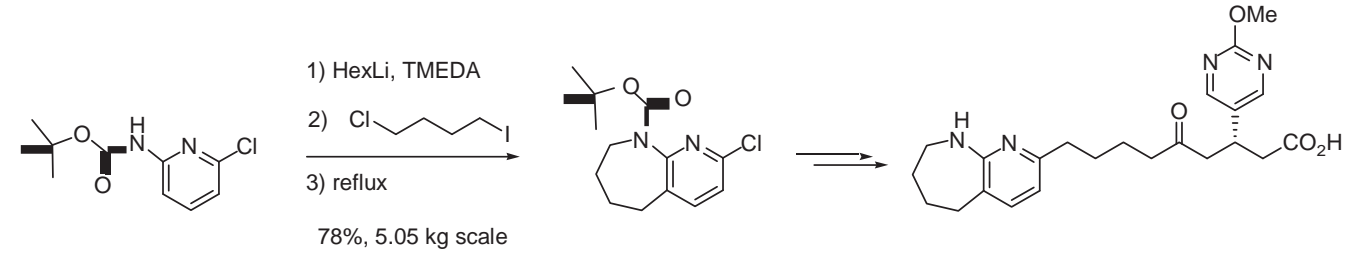

Scheme 1. Merck process route to a tetrahydroazepine.<smiles>[R]CC1CCC(=O)N([R1])c2cc(Cl)nc(Cl)c21</smiles>

3

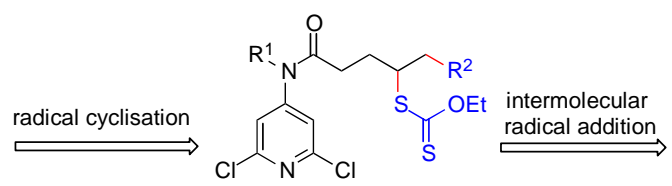

2<smiles>[R1]N(C(=O)CCC=C)c1cc(Cl)nc(Cl)c1</smiles>

1

Scheme 2. Retrosynthetic analysis.

observed. While this failure may be attributed to the slow rotation around the amide bond and the predominance of the geometrically non-desired rotamer, this result must be contrasted with the surprisingly successful formation of a six-membered ring starting with an unsubstituted amide as in the first transformation shown in Scheme 3. ${ }^{3 a}$

The methyl group was chosen as the substituent on the amide nitrogen. The preparation of olefin 1a was executed in two steps. Reaction between 4-amino-2,6-dichloropyridine and 4-pentenoic acid chloride in the presence of diisopropylethylamine provided the corresponding secondary amide in $97 \%$ yield. Treatment of the latter with methyl iodide in acetone in the presence of potassium carbonate in a sealed vessel gave olefin $1 \mathrm{a}$ in $93 \%$ yield. The intermolecular radical addition of the xanthate derived from chloroacetone proceeded smoothly under standard conditions [sub-stoichiometric quantities of dilauroyl peroxide (DLP) in refluxing ethyl acetate] furnishing xanthate $2 a$ in a good yield (61\%). With this new xanthate in hand, the stage was set for the radical cyclisation. The first attempt using stoichiometric amounts of DLP in refluxing ethyl acetate resulted in a disappointingly poor yield $(10 \%)$ of the desired heterocycle $3 a$, along with the prematurely reduced compound 4 (15\%) and a complex mixture of more polar by-products. These by-products were identified by HPLC/MS and crude NMR analysis as dimeric bicyclic compounds present as a mixture of regio and atropoisomers. For the sake of clarity only two of these, 5 and 6 , are shown (Scheme 4).

This was the first time such dimers were observed in the course of a radical cyclisation onto a pyridine ring. The radical cyclisation process usually entails four main steps. First, the radical is generated from the corresponding xanthate by the action of the peroxide under thermal conditions. Second, the key cyclisation event leads to a delocalised dihydropyridinyl radical. Third, the oxidation of this radical by the peroxide (used in stoichiometric amounts) by a one-electron transfer precedes the fourth and final rearomatisation steps through loss of a proton. In the present case, the oxidation of the dihydropyridinyl radical is clearly a relatively slow process. The lifetime of this radical intermediate is extended and its concentration therefore increases to the point where selfcoupling becomes a very significant side reaction. Loss of two molecules of hydrochloric acid from the resulting dimer furnishes the observed dimeric products 5 and 6 and their various isomers. These mechanistic features are summarised in Scheme 5 (only one isomer is shown).<smiles>C=CCC(=O)Nc1cc(Cl)nc(Cl)c1</smiles><smiles>CCOC(=O)CSC(=S)OCC</smiles>
$82 \%$<smiles>CCOC(=O)CCC(CC(=O)Nc1cc(Cl)nc(Cl)c1)SC(=S)OCC</smiles>

$51 \%$<smiles>CCOCCCC1CC(=O)Nc2cc(Cl)nc(Cl)c21</smiles><smiles>C=CC(OCC)OCC</smiles><smiles>CCOC(=S)SC(CCC(=O)Nc1cc(Cl)nc(Cl)c1)C(CC)OCC</smiles><smiles>CCOC(OC)C1CCC(=O)Nc2cc(Cl)nc(Cl)c21</smiles><smiles>CCOC(CCCC(=O)Nc1cc(Cl)nc(Cl)c1)OCC</smiles> 
<smiles>C=CCCC(=O)N(C)c1cc(Cl)nc(Cl)c1</smiles><smiles>CCOC(=S)SCC(C)=O</smiles><smiles>[M]C(=O)CCC(CCC(=O)N(C)c1cc(Cl)nc(Cl)c1)SC(=S)OC</smiles>

$2 a$

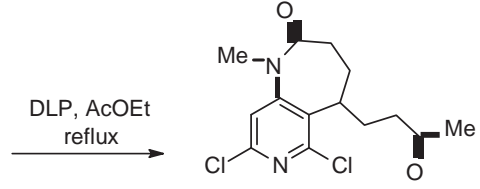

$3 a$<smiles>CC(=O)CCCCCC(=O)N(C)c1cc(Cl)nc(Cl)c1</smiles>

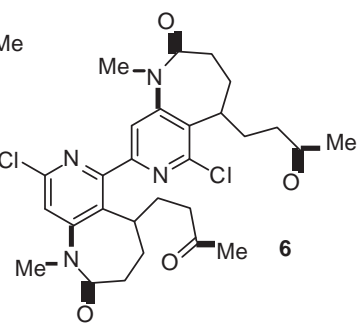

Scheme 4. Products from a first cyclisation attempt.

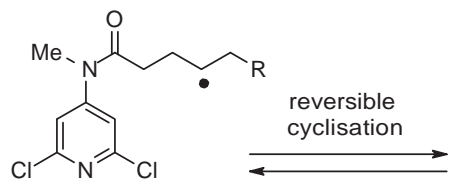

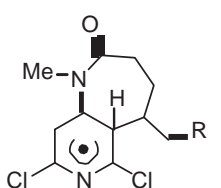

dimerisation

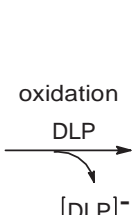

[DLP]-<smiles>[R]CC1CCC(=O)N(C)[C@H]2CC(Cl)=NC(Cl)=C12</smiles><smiles>[R]CC1CCC(=O)N(C)c2cc(Cl)nc(Cl)c21</smiles>

reduction<smiles>[R]CCCCC(=O)N(C)c1cc(Cl)nc(Cl)c1</smiles>

4

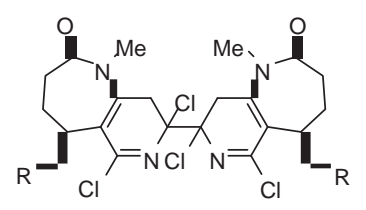

C
$-2 \mathrm{HCl}$

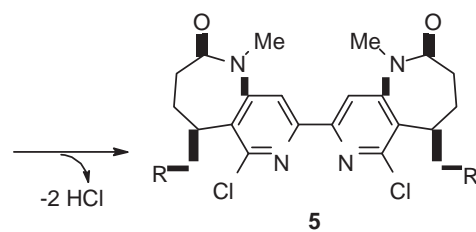

5

Scheme 5. Mechanistic outcomes.

The lifetime of a peroxide is exponentially dependent on the temperature. Thus, the half-life of lauroyl peroxide (DLP) is $60 \mathrm{~min}$ at $85 \mathrm{oC}$. It is extended to 10 hours at $65 \mathrm{oC}$. Therefore, by decreasing the temperature of the reaction mixture to $73-75 \mathrm{oC}$, the quantity of DLP available for the oxidation process is greater. Improved yields of 3 a varying from $20 \%$ to $25 \%$ were attained using this straightforward modification. However, these yields were still far from being useful from a preparative standpoint. We therefore decided to incorporate a co-oxidant to accelerate the formation of the dihydropyridinyl cation and shut down more effectively the unwanted path to the dimers. Dibenzoylperoxide (DBP) has a half-life of 60 min at 95 oC and is known to be a better oxidant than lauroyl peroxide. ${ }^{7}$ By keeping the lower temperature of 73-75 oC, only the lauroyl peroxide will thermally decompose and start the radical process, whereas the benzoyl peroxide will be present in a sufficiently large concentration to accomplish the desired oxidation of the dihydropyridinyl radical intermediate. Indeed, we found that using 1.1 equiv of DBP and adding $20 \mathrm{~mol} \%$ of DLP every $60 \mathrm{~min}$ at $73-75 \mathrm{oC}$ limited strongly the formation of the dimers and provided the desired dihydropyridoazepinone 3a in $60 \%$ yield. $^{8}$ It should be noted that it is really the synergistic effect of both peroxides that allows the cyclisation to proceed, as a blank experiment with benzoyl peroxide alone was not successful. Even if this yield is rather moderate, it represents a six-fold increase in comparison with the initial yield observed under non-optimised conditions. It must also be remembered that cyclisations onto aromatic structures leading to the direct formation of fused sevenmembered rings are inherently difficult and almost impossible to accomplish with classical methods. The optimised conditions were then applied to the preparation of a series of novel pyridoazepinones starting from compound $1 \mathrm{a}$ and the results are displayed in Table 1.

The reaction conditions proved to be compatible with a variety of functionalities and allowed the straigthforward synthesis of a series of original heterocycles. Ketones, esters, malonates and even sensitive a-chloroketones were well tolerated. The use of xanthate derived from an acetophenone represents however a limitation of the method. The radical generated from xanthate $2 \mathrm{j}$ can cyclise 
Table 1

Intermolecular additions and subsequent cyclisations

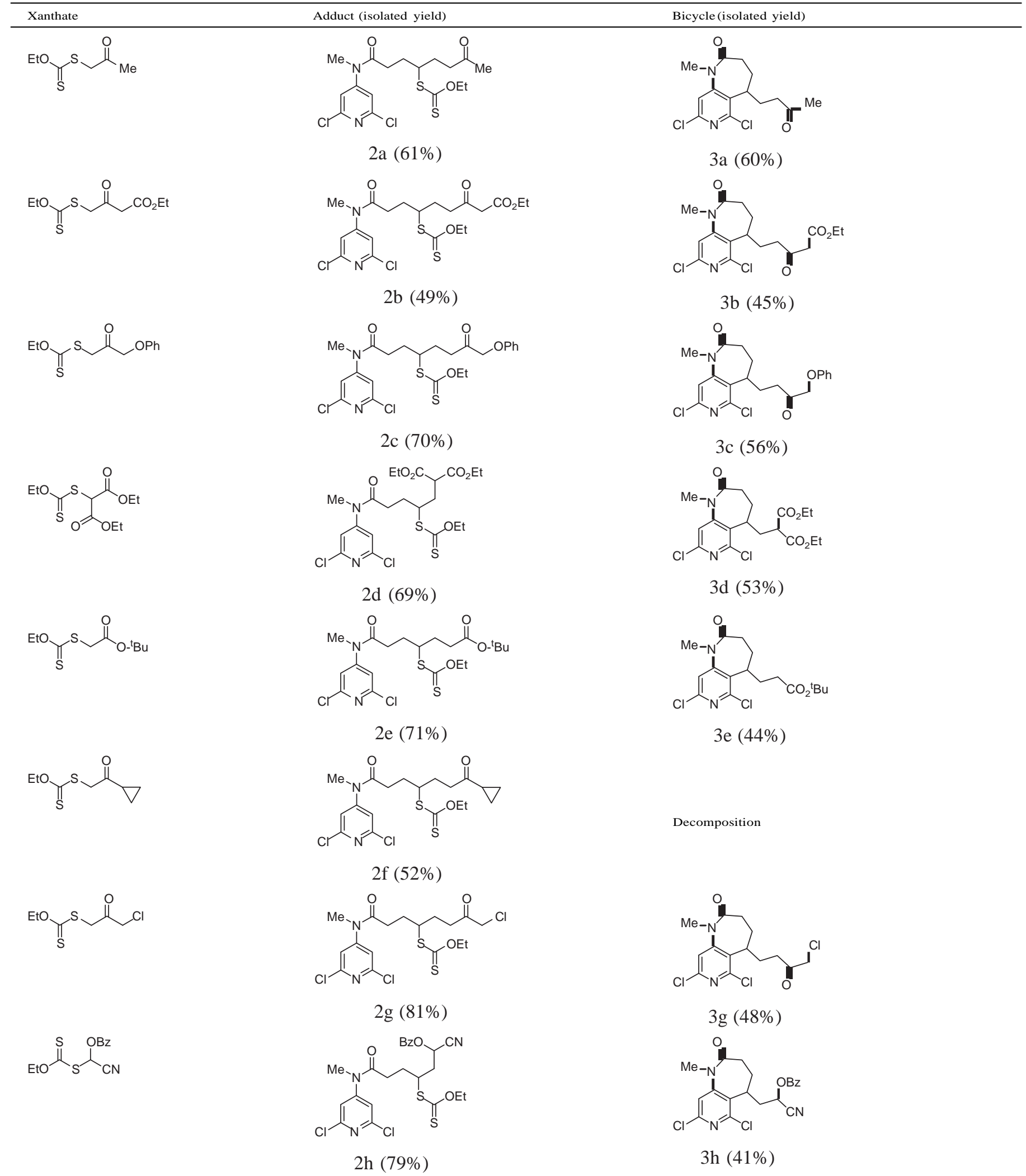




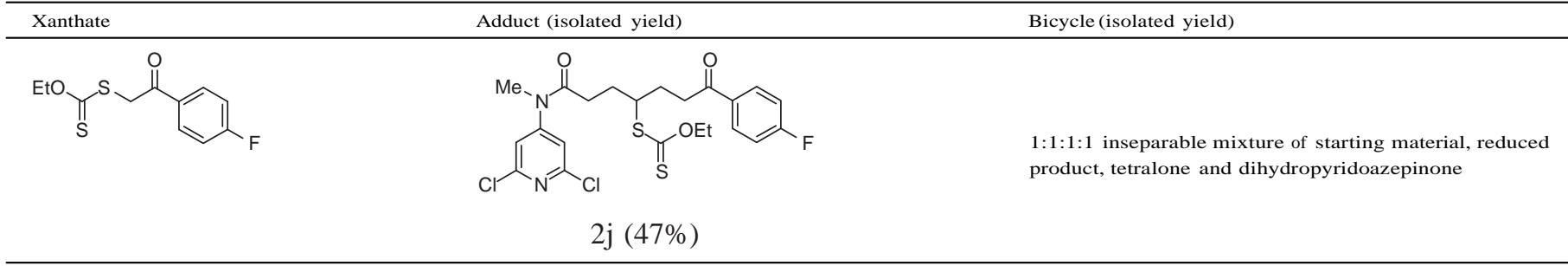

onto the phenyl ring to generate the corresponding tetralone or onto the pyridine ring and no chemoselectivity was observed. Surprisingly, the cyclopropane moiety was readily introduced by the intermolecular radical addition (compound 2f), but did not survive the cyclisation reaction conditions. The reasons underlying this behaviour are not clear at the moment.

In summary, we have developed a new radical based method for the preparation of 5-substituted 4,5-dihydro-3H-pyrido[4,3-b]azepin-2-ones. This sequence complements nicely the rare existing approaches and allows access to a family of structures not readily available hitherto. We also demonstrated the large scope of this procedure by applying it to the synthesis of a series of novel pyridoazepinone derivatives. This process allows the introduction, at the 5-position of the pyridoazepinone, of a variety of functional groups, and these can be further elaborated into unique, more complex structures. From a more fundamental perspective, this work has provided us with a better appreciation of some subtle aspects of the ring-closure mechanism and perhaps a means to improve the efficacy of radical cyclisations onto aromatic rings by the use of a combination of cheap, commercially available peroxides.

\section{References and notes}

1. For reviews, see: (a) Henry, G. D. Tetrahedron 2004, 60, 6043; (b) Popowycz, F.; Routier, S.; Joseph, B.; Mérour, J.-Y. Tetrahedron 2007, 63, 1031; (c) Popowycz, F.; Mérour, J.-Y.; Joseph, B. Tetrahedron 2007, 63, 8689; (d) Song, J. J.; Reeves, J. T. Gallou, F.; Tan, Z.; Yee, N. K.; Senanayake, C. H. Chem. Soc. Rev. 2007, 36, 1120; (e) Schirok, H. J. Org. Chem. 2006, 71, 5538; (f) Humphrey, G. R.; Kuethe, J. T. Chem. Rev. 2006, 106, 2875; (g) Cacchi, S.; Fabrizi, G. Chem. Rev. 2005, 105, 2873.

2. (a) Quiclet-Sire, B.; Zard, S. Z. Pure Appl. Chem. 2011, 83, 519; (b) Quiclet-Sire, B.; Zard, Z. S. Chem. Eur. J. 2006, 12, 6002; (c) Quiclet-Sire, B.; Zard, Z. S. Top. Curr. Chem. 2006, 264, 201; (d) Zard, S. Z. In Radicals in Organic Synthesis; Renaud, P., Sibi, M. P., Eds.; Wiley-VCH: Weinheim, 2001; Vol. 1, p 90; (e) Quiclet-Sire, B.; Zard, S. Z. Phosphorus, Sulfur Silicon 1999, 153-154, 137; (f) Quiclet-Sire, B.; Zard, S. Z. J. Chin. Chem. Soc. 1999, 46, 139; (g) Zard, S. Z. Angew. Chem., Int. Ed. 1997, 36, 672
3. (a) Bacqué, E.; El Qacemi, M.; Zard, S. Z. Heterocycles 2012, 84, 291; (b) Bacqué, E.; El Qacemi, M.; Zard, S. Z. Org. Lett. 2004, 6, 3671. See also: (c) Laot, Y.; Petit, L.; Tran, N. D. M.; Zard, S. Z. Aust. J. Chem. 2011, 64, 416; (d) Laot, Y.; Petit, L.; Zard, S. Z. Org. Lett. 2010, 12, 3426; (e) Laot, Y.; Petit, L.; Zard, S. Z. Chem. Commun. 2010, 46, 5784; (f) El Qacemi, M.; Ricard, L.; Zard, S. Z. Chem. Commun. 2006, 4422.

4. Keen, S. P.; Cowden, C. J.; Bishop, B. C.; Brands, K. M. J.; Davies, A. J.; Dolling, U. H.; Lieberman, D. R.; Stewart, G. W. J. Org. Chem. 2005, 70, 1771.

5. Spivey, A. C.; Fekner, T.; Adams, H. Tetrahedron Lett. 1998, 39, 8919.

6. (a) Moehrle, H.; Dwuletzki, H. Chem. Ber. 1986, 119, 3600; (b) Stukenbrock, H.; Mussmann, R.; Geese, M.; Ferandin, Y.; Lozach, O.; Lemcke, T.; Simone Kegel, S.; Lomow, A.; Burk, U.; Dohrmann, C.; Meijer, L.; Austen, M.; Kunick, C. J. Med. Chem. 2008, 51, 2196; (c) Egert-Schmidt, A.-M.; Dreher, J.; Dunkel, U.; Kohfeld, S.; Preu, L.; Weber, H.; Ehlert, J. E.; Mutschler, B.; Totzke, F.; Schächtele, C.; Kubbutat, M. H. G.; Baumann, K.; Kunick, C. J. Med. Chem. 2010, 53, 2433.

7. Fraind, A.; Turncliff, R.; Fox, T.; Sodano, J.; Ryzhkov, L. R. J. Phys. Org. Chem. 2011 24, 809. and references cited therein.

8. Typical cyclisation procedure: A three-necked round bottomed flask equipped with a water condenser and a thermometer was charged with the appropriate xanthate 2 (1.0 mmol). EtOAc $(15 \mathrm{~mL})$ was added and the solution was refluxed for $10 \mathrm{~min}$ under a nitrogen atmosphere. The temperature of the solution was then decreased to $73-75 \mathrm{oC}$ and dibenzoylperoxide $(1.1 \mathrm{mmol})$ was added in one portion. Lauroyl peroxide was then added $(20 \mathrm{~mol} \%)$ and additional portions ( $20 \mathrm{~mol} \%$ ) were added every $60 \mathrm{~min}$ until total consumption of the xanthate. The mixture was then cooled to room temperature and the solvent was removed under reduced pressure. The residue was purified by flash chromatography on silica gel to yield the corresponding dihydropyridoazepinone. An example is the synthesis of 6,8-dichloro-1-methyl-5-(3-oxo-4-phenoxybutyl)-4,5-dihydro-1Hpyrido[4,3-b]azepin-2(3H)-one (3c): Following the general procedure the radical cyclisation was carried out starting with xanthate 2c (300 mg, $0.538 \mathrm{mmol})$ in EtOAc $(8 \mathrm{~mL})$. Dibenzoyl peroxide $(75 \%$ purity, the remainder is water; $195 \mathrm{mg}, 1.1$ equiv.) was used and the reaction needed $100 \mathrm{~mol} \%$ of DLP to go to completion. Purification by flash chromatography on silica gel (petroleum ether/EtOAc 1:1) yielded bicycle 3c (123 mg, 56\%). ${ }^{1} \mathrm{H}$ NMR $\left(400 \mathrm{MHz}, \mathrm{CDCl}_{3}\right): \mathrm{d}_{\mathrm{H}} 8.03(\mathrm{~d}, \mathrm{~J}=7.3 \mathrm{~Hz}, 2 \mathrm{H}), 7.59(\mathrm{t}, \mathrm{J}=7.5 \mathrm{~Hz}, 1 \mathrm{H}), 7.43(\mathrm{t}$, $\mathrm{J}=7.7 \mathrm{~Hz}, 2 \mathrm{H}), 7.05(\mathrm{~s}, 1 \mathrm{H}), 4.73(\mathrm{~s}, 2 \mathrm{H}), 3.71(\mathrm{~m}, 1 \mathrm{H}), 3.30(\mathrm{~s}, 3 \mathrm{H}), 2.47-2.35(\mathrm{~m}$, $3 \mathrm{H}), \quad 2.32-2.25(\mathrm{~m}, 2 \mathrm{H}), 2.17-2.14(\mathrm{~m}, 1 \mathrm{H}), 2.02-1.91(\mathrm{~m}, 2 \mathrm{H}) ;{ }^{13} \mathrm{C}$ NMR (100 MHz, CDCl3): $\mathrm{d}_{\mathrm{c}} 202.6$ (C), 172.1 (C), 165.7 (C), 155.1 (C), 151.5 (C), 149.1 (C), $133.4(\mathrm{CH}), 129.8(2 \mathrm{CH}), 129.0(\mathrm{C}), 128.5(2 \mathrm{CH}), 117.5(\mathrm{CH}), 68.2\left(\mathrm{CH}_{2}\right), 37.2$ (CH), 36.8 $\left(\mathrm{CH}_{2}\right), 35.1\left(\mathrm{CH}_{3}\right), 32.8\left(2 \mathrm{CH}_{2}\right), 27.2\left(\mathrm{CH}_{2}\right)$; IR $\left(\mathrm{CCl}_{4}\right): \mathrm{m}_{\max } 3155,2935$, $1730,1688,1567,1272$. HRMS (EI+): Calcd for $\mathrm{C}_{20} \mathrm{H}_{20} \mathrm{O}_{3} \mathrm{~N}_{2} \mathrm{Cl}_{2}$ : 406.0851. Found 406.0860. 